\title{
Expression of Xylella fastidiosa RpfF in Citrus Disrupts Signaling in Xanthomonas citri subsp. citri and Thereby Its Virulence
}

\author{
R. Caserta, ${ }^{1,2}$ S. C. Picchi, ${ }^{1}$ M. A. Takita, ${ }^{1}$ J. P. Tomaz, ${ }^{3}$ W. E. L. Pereira, ${ }^{1,2}$ M. A. Machado, ${ }^{1}$ M. Ionescu, ${ }^{4}$ \\ S. Lindow, ${ }^{4}$ and A. A. De Souza ${ }^{1}$ \\ ${ }^{1}$ Centro de Citricultura Sylvio Moreira/Instituto Agronomico de Campinas, Cordeirópolis, 13490000, Sao Paulo, Brazil; \\ ${ }^{2}$ Universidade Estadual de Campinas-UNICAMP, Campinas, 13083-970, Sao Paulo, Brazil; ${ }^{3}$ Instituto Agronomico do Parana- \\ IAPAR, Londrina, 86047-902, Parana, Brazil; ${ }^{4}$ Department of Plant and Microbial Biology University of California, Berkeley, \\ 94720, California, U.S.A.
}

Submitted 27 March 2014. Accepted 13 July 2014.

\begin{abstract}
Xylella fastidiosa and Xanthomonas citri subsp. citri, that cause citrus variegated chlorosis (CVC) and citrus canker diseases, respectively, utilize diffusible signal factor (DSF) for quorum sensing. DSF, produced by RpfF, are similar fatty acids in both organisms, although a different set of genes is regulated by DSF in each species. Because of this similarity, Xylella fastidiosa DSF might be recognized and affect the biology of Xanthomonas citri. Therefore, transgenic Citrus sinensis and Carrizo citrange plants overexpressing the Xylella fastidiosa rpfF were inoculated with Xanthomonas citri and changes in symptoms of citrus canker were observed. $X$. citri biofilms formed only at wound sites on transgenic leaves and were thicker; however, bacteria were unable to break through the tissue and form pustules elsewhere. Although abundant growth of $X$. citri occurred at wound sites on inoculated transgenic leaves, little growth was observed on unwounded tissue. Genes in the DFS-responsive core in $X$. citri were downregulated in bacteria isolated from transgenic leaves. DSF-dependent expression of engA was suppressed in cells exposed to xylem sap from transgenic plants. Thus, altered symptom development appears to be due to reduced expression of virulence genes because of the presence of antagonists of DSF signaling in $X$. citri in rpfF-expressing plants.
\end{abstract}

Intercellular communication mediated by diffusible signals is a well-known feature among bacteria, and its use to control cell-density-dependent gene expression is often called quorum sensing (QS). Such signaling enables modulation of transcription in an environmental-context manner (Kaplan and Greenberg 1985). Both synthases and sensors of such signals are encoded by specific clusters of genes (Novick et al. 1995; Seed et al. 1995). Various bacteria synthesize different signal molecules, including acyl homoserine lactones (AHL), cyclic dipeptides, bradyoxetin, and unsaturated fatty acids known as diffusible signal factors (DSF) (Gonzales and Keshavan 2006). Regardless of the organism, signaling depends on perception of molecular signals, which increase in local concentration along with cell numbers, by a sensory protein. Upon binding, a

Correspondent author: A. A. de Souza;

E-mail: alessandra@centrodecitricultura.br

(C) 2014 The American Phytopathological Society cascade of phosphorylation is triggered and expression of a variety of downstream genes is differentially modulated.

Although cognate signal molecules that bind to sensory proteins lead to appropriate changes in gene expression, heterologous molecules similar in structure can also interact with such receptors, leading to suppression of downstream signaling. Examples of such antagonistic molecules produced either by bacteria or eukaryotes capable of blocking QS systems have been described (González and Keshavan 2006). For example, the furanone produced by the red alga Delisea pulchra mimics the AHL produced by the bacterium Serratia liquefaciens and, thus, interferes with its QS behavior due to its unstable binding to LuxR homologs and rapid disruption of QS-mediated gene regulation (Manefiled et al. 2002). The interference in QS regulation by furanones was also shown for other bacteria, resulting in a reduction in biofilm formation and swarming motility in Escherichia coli and luminescence in Vibrio harvey (Ren et al. 2001).

In Xanthomonas spp. as well as in Xylella fastidiosa, the cluster involved in production and perception of QS signals is called $r p f$, for "regulation of pathogenicity factors". Although this system differs somewhat between these species, there are many similarities in the structure of the signal molecules and the means by which they are perceived. Three of the genes that comprise this system ( $r p f F, r p f C$, and $r p f G)$ are present in both taxa. In both bacteria, $r p f F$ encodes a DSF synthase and $r p f C$ encodes a sensor protein that, when activated by DSF binding, activates the regulatory protein RpfG which, in turn, modulates intracellular levels of cyclic di-GMP due to its phosphodiesterase activity (de Souza et al. 2013). Although RpfF is involved in both production and sensing DSF in X. fastidiosa (Ionescu et al. 2013), sensing of DSF does not depend on RpfF in Xanthomonas spp. The accumulation of DSF modulates the expression of different sets of genes in X. fastidiosa and Xanthomonas spp. DSF increases the production of cell surface adhesins and suppresses the expression of extracellular enzymes and, thus, tends to reduce the virulence of $X$. fastidiosa because these more adherent cells exhibit less movement along and between grapevine xylem vessels. Interestingly, these cells were easily acquired by insect vectors (Chatterjee et al. 2008a). In contrast, a variety of virulence genes and motility are upregulated in the presence of DSF in Xanthomonas spp. (Chatterjee et al. 2008b; Dow et al. 2003; Guo et al. 2012). Disruption of DSF signaling in Xanthomonas citri pv. citri revealed a core of virulence genes associated with movement, endoglucanases, and the type III secretion system (T3SS) that are upregulated by DSF. Blockage of 
DSF production also reduced attachment to leaves as well as disease symptoms (Guo et al. 2012).

The DSF molecules produced by Xylella fastidiosa and Xanthomonas spp. are similar but apparently different. $X$. fastidiosa Temecula strain, causal agent of Pierce's disease, produces $2(Z)$ tetradecenoic acid, while 12-methyltetradecenoic acid was isolated from a $X$. fastidiosa strain that causes citrus variegated chlorosis (CVC). In contrast, various Xanthomonas strains produce 2(Z)-11-methyldodecenoic acid, (2Z,5Z)-11-methyldodecadienoic acid, and 2(Z)-dodecenoic acid (Beaulieu et al. 2013; He et al. 2010; Simionato et al. 2007; Wang et al. 2004). Perhaps not surprising, given taxa appear to be maximally responsive to

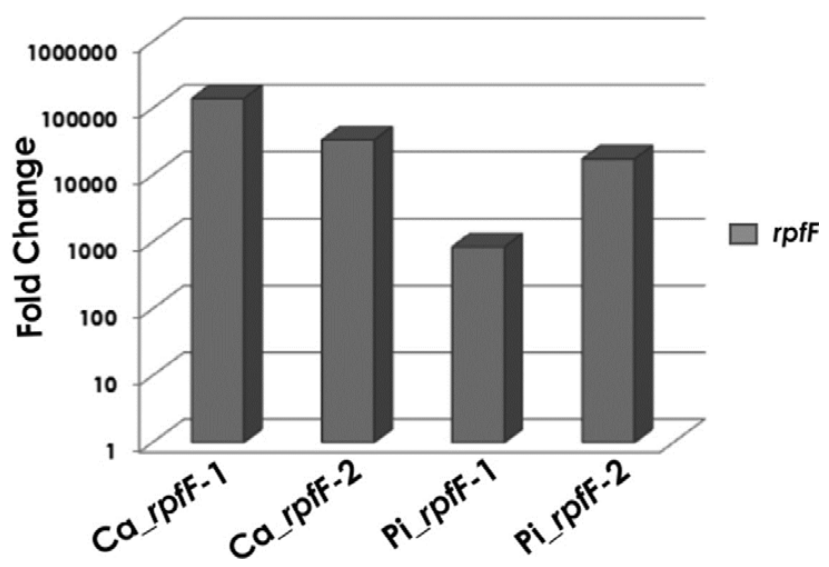

Fig. 1. Transgene expression in transformed plants. Quantitative expression of $r p f F$ in transgenic plants in comparison to the wild type. Ca_rpfF-1 and $\mathrm{Ca} \_r p f F-2$ refer to Carrizo citrange transgenic plants and Pi_rpfF-1 and $\mathrm{Pi} r p f F-2$ refer to Pineapple sweet orange transgenic plants. the dominant DSF that they produce. For example, $X$. fastidiosa was responsive to much lower concentrations of 2(Z)-tetradecenoic acid than was Xanthomonas campestris pv. campestris (Beaulieu et al. 2013). Circumstantial evidence also suggests that the DSF synthase RpfF may be rather promiscuous, with the DSF species produced dependent on the host cell into which it is introduced. For example, when introduced into grape, the RpfF conferred the production of not only $2(Z)$-tetradecenoic acid but also 2(Z)-11-methyldodecenoic acid and 2-Z hexadecenoic acid, two compounds that were not previously found in cultures of Xylella fastidiosa (Lindow et al. 2014). Apparently, sufficient quantities of DSF species to which $X$. fastidiosa was responsive were produced in these transgenic grape plants to alter the behavior of this pathogen, because its movement through the plant and, hence, its virulence was greatly reduced in the $r p f F$-transformed plants compared with the wild type (WT) (Lindow et al. 2014). Given that CVC strains of $X$. fastidiosa produce DSF species, although perhaps different from those produced by other $X$. fastidiosa and Xanthomonas spp., we introduced the $r p f F$ from a CVC strain of $X$. fastidiosa into citrus genotypes to address whether a process of pathogen confusion might lead to reduced susceptibility to other bacterial diseases of citrus. However, given that Xanthomonas citri modulates its expression of its virulence factors in response to accumulation of DSF, we posited that citrus expressing Xylella fastidiosa rpfF might also exhibit altered susceptibility to citrus canker disease, depending on which DSF species would be made in this heterologous host. If the DSF species produced in citrus activated the RpfC-mediated QS system in Xanthomonas citri, it might be expected that the trees would exhibit higher susceptibility to this pathogen. In contrast, heterologous DSF species produced in such transgenic trees might antagonize the native DSFmediated gene expression system in $X$. citri, resulting in
A
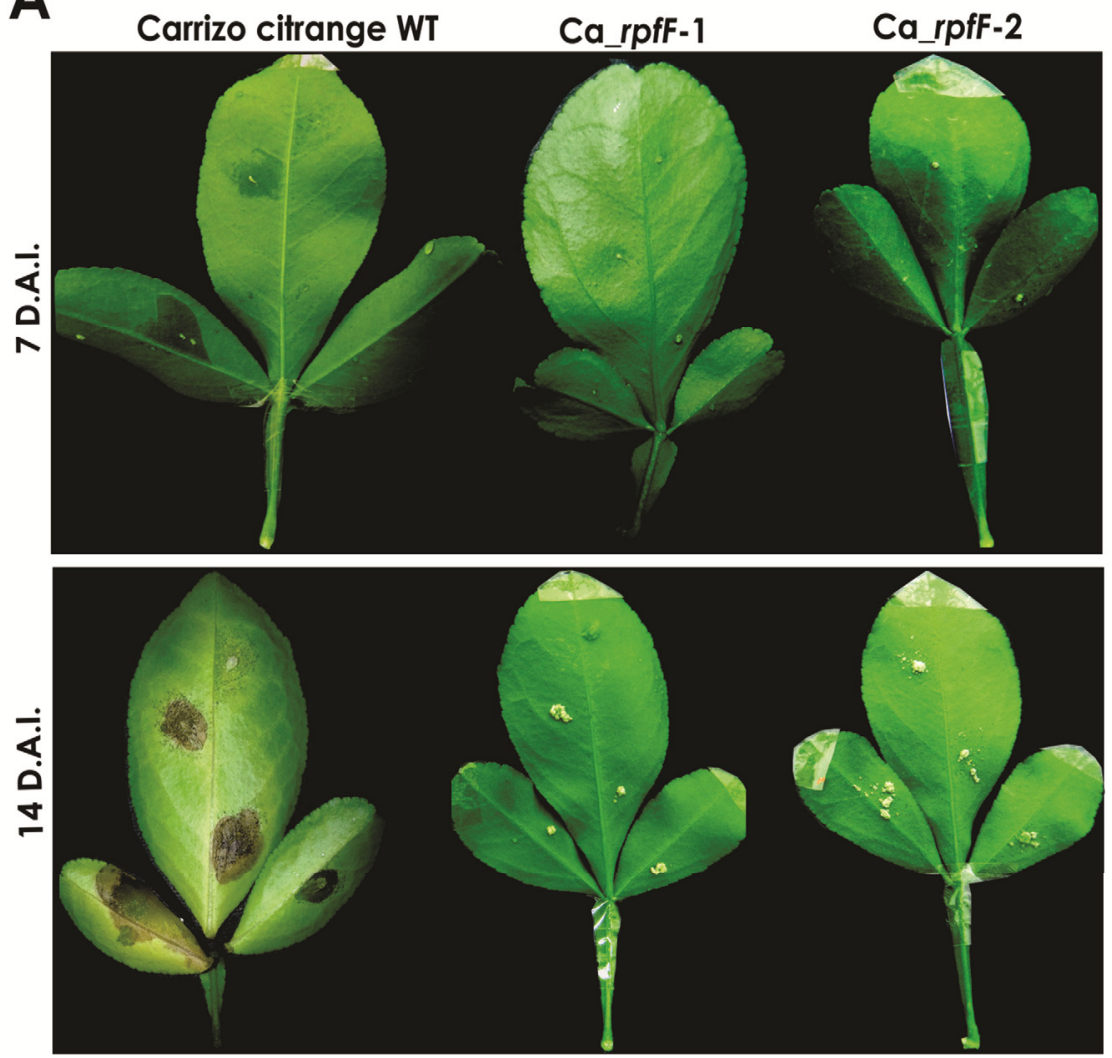

Ca_rpfF-2

Ca_rpfF-1

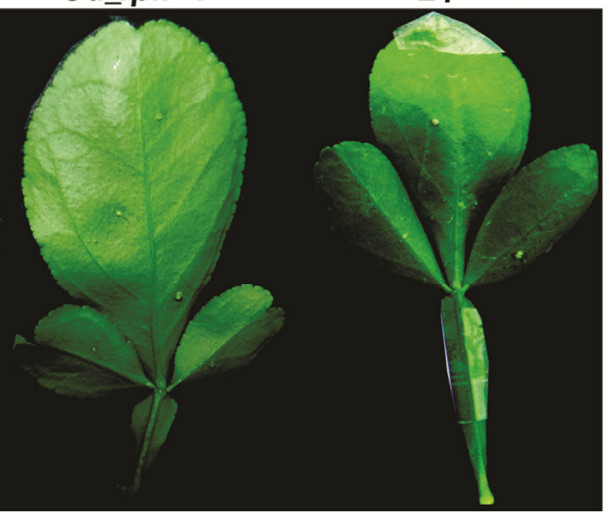

B Pineapple
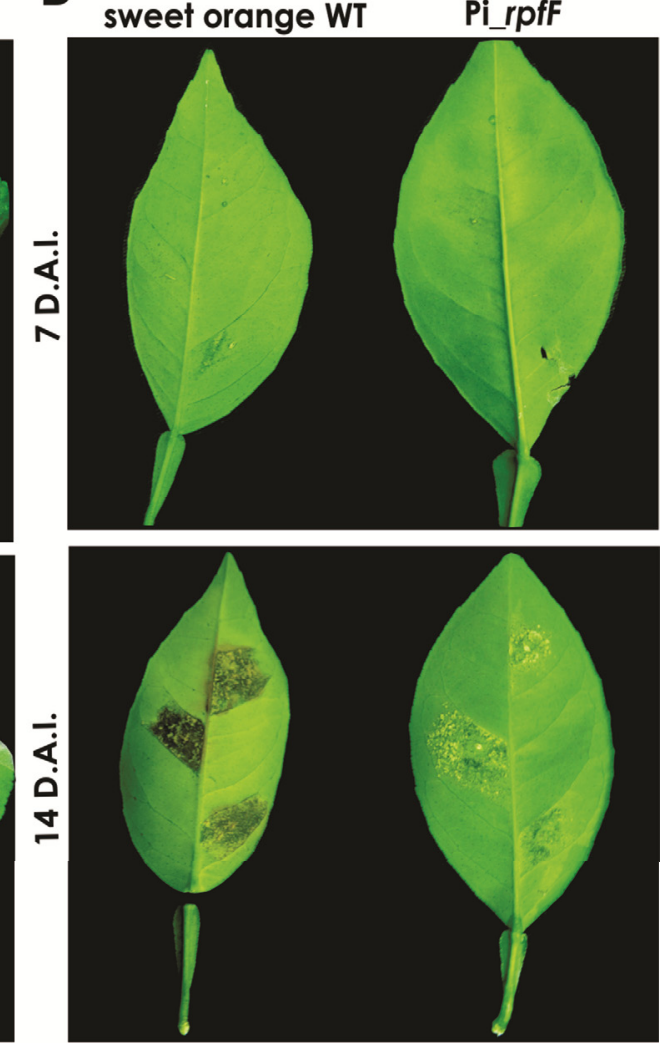

Fig. 2. Citrus canker symptoms. Xanthomonas citri_GFP was infiltrated in leaves of wild-type (WT) and transgenic plants and evaluated at 7 and 14 days after inoculation (D.A.I.). A, Carrizo citrange and B, Pineapple sweet orange. 
reduced disease susceptibility. In this study, we show that these transgenic lines exhibited greatly reduced susceptibility to citrus canker disease, apparently by the suppression of virulence traits in $X$. citri, presumably by interfering with its intrinsic cell-cell communication process.

\section{RESULTS}

\section{Transformed citrus plants highly express $r p f F$.}

The $r p f F$ gene from Xylella fastidiosa was successfully introduced into different citrus genotypes by Agrobacterium tumefaciens using the vector pCambia2301. Five Carrizo citrange (Citrus sinensis L. Osb. $\times$ Poncirus trifoliata (L.) Raf.) and seven Pineapple sweet orange (C. sinensis L. Osb.) transformants were obtained and confirmed by polymerase chain reaction (PCR) (data not shown). The expression of $r p f F$ was determined by quantitative reverse-transcriptase (qRT)-PCR and high levels were observed for two Carrizo citrange and two Pineapple sweet orange plants (Fig. 1). Ten buds from each of these plants were used for grafting onto Rangpur lime plants to enable subsequent studies. To identify the presence of chimeras, $\beta$-glucuronidase (GUS) assays were performed on the leaves of propagated plants; although no chimeric Carrizo citrange plants were obtained, some Pineapple sweet orange plants were chimeric (data not shown) and, therefore, only GUS-positive leaves from nonchimeric plants were used. Plants were also screened for their susceptibility to symptom development conferred by Xanthomonas citri after leaf infiltration. Surprisingly, many such plants exhibited greatly reduced disease susceptibility, and those budded plants with a lower susceptibility were the source of material for subsequent studies; those derived from Carrizo citrange will hereafter be re- ferred to as $\mathrm{Ca} \_r p f \mathrm{~F}-1$ and $\mathrm{Ca} \_r p f \mathrm{~F}-2$ while those from Pineapple sweet orange will be referred to as $\mathrm{Pi} r p f \mathrm{~F}$.

\section{Pattern of symptom development differs in $r p f F$-expressing citrus leaves.}

Because the severity of citrus canker in leaves of the $r p f F$ expressing citrus cultivars was noticeably different than that in WT plants, more detailed measurements of pathogen growth and symptom development in these plants were made to better understand the apparent differences in susceptibility of these lines. Canker symptoms were evaluated in leaves 7 and 14 days after a green fluorescent protein (GFP)-marked strain of $X$. citri was infiltrated into leaves. Large differences in the appearance of lesions on $r p f F$-expressing plants were observed compared with that on WT plants. The appearance of lesions formed in leaves of $r p f F$-expressing plants after infiltration differed from the typical symptoms of citrus canker (Brunings and Gabriel 2003). Although lesions with erumpent pustules, some of which had water-soaked fringes, were apparent on WT leaves by 7 days after inoculation, the lesions on the leaves of transgenic plants were smaller and none had any associated water soaking. Those few lesions that had developed on transgenic leaves appeared "dry" and were smaller (Fig. 2A and B) and no hyperplasia of leaf tissue was seen within 7 days. Given that relatively low concentrations of cells were infiltrated into the leaves (approximately 500 cells/site), it was noteworthy that discreet sites of GFP fluorescence, apparently associated with localized multiplication of cells of the $X$. citri strain within tissues, was apparent 7 days after inoculation in both WT and transgenic leaves. Importantly, although large numbers of punctate sites of GFP fluorescence were observed in WT plants throughout the region which had been infiltrated with bacterial inoculum, a
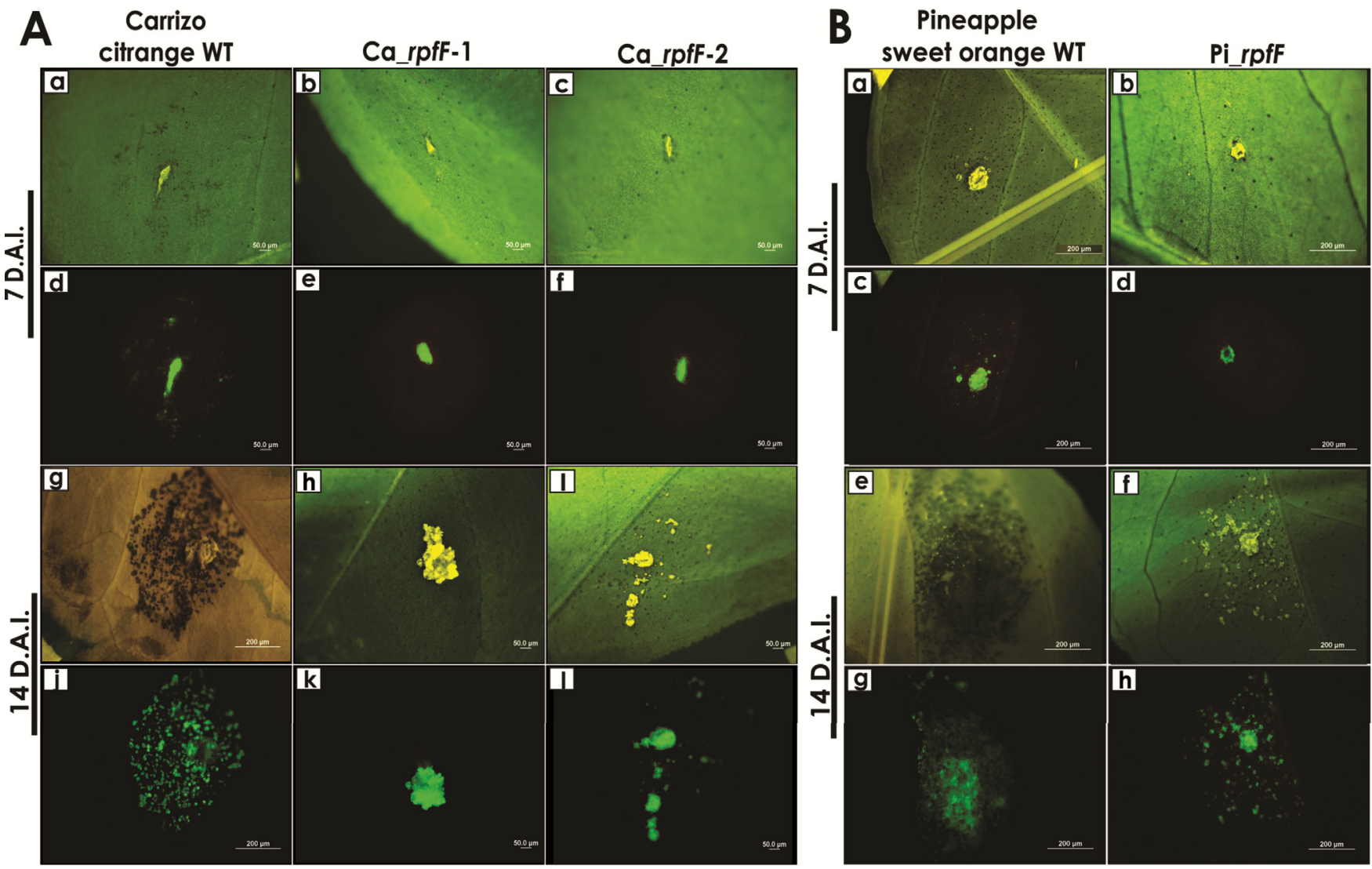

Fig. 3. Microscopy analysis of citrus canker lesions. A, Carrizo citrange and B, Pineapple sweet orange plants. Green labeling refers to $X$ citri_GFP Xanthomonas citri_GFP was infiltrated in leaves of wild-type (WT) and transgenic plants and was evaluated at 7 (a, b, c, d, e, and f) and 14 (g, h, i, j, k, and l) days after inoculation (D.A.I.) under light (a, b, $\mathbf{c}, \mathbf{g}, \mathbf{h}$, and $\mathbf{i})$ and fluorescence microscopy $(\mathbf{d}, \mathbf{e}, \mathbf{f}, \mathbf{j}, \mathbf{k}$, and $\mathbf{l})$. 
single large site of GFP fluorescence, coincident with the injured point of inoculation into a given leaf, was observed on rpfF-expressing plants (Fig. 3). Because the number of discrete sites of GFP fluorescence in WT leaves was similar to the number of cells that had been infiltrated into the tissue, we presume that these represent microcolony development within the tissue of WT leaves. The absence of corresponding sites of GFP fluorescence in the transgenic leaves suggested that $X$. citri exhibited much less multiplication in these plants. The differences in the number and appearance of lesions in WT and transgenic plants were even more striking by 14 days after infiltration. Lesions in WT leaves exhibited dramatic tissue hypertrophy, with large pustules and abundant associated water soaking and occasional abscission of the petiole; such characteristics were not observed in transgenic leaves (Fig. 2A and B). Intact, nondetached leaves on greenhouse-grown RpfF-expressing plants exhibited the same difference in disease symptoms observed in detached leaves (data not shown).

Given that no punctate florescent microcolonies were observed away from the point of inoculation in transgenic leaves, suggesting a lack of growth of the marked strains of $X$. citri, we directly assessed the population size of this strain at various times in such undamaged tissues. Although modest increases ( $<8$-fold) in population size of $X$. citri were observed in WT Pineapple sweet orange plants as well as in transgenic Pineapple sweet orange and Carrizo citrange plants by 7 days after inoculation, large increases in population size ( $>50$-fold) were observed in WT Carrizo citrange plants (Fig. 4). Importantly, by 14 days after inoculation, the population sizes of $X$. citri in WT Carrizo citrange and Pineapple sweet orange plants were from 200- to 2,000-fold higher than in the transgenic rpfFexpressing plants; the population size of $X$. citri in the transgenic plants was similar to or lower than that at the time of inoculation in these damaged tissues. Likewise, when infiltrated into intact leaves on RpfF-expressing plants in the greenhouse, the population dynamics of $X$. citri was similar to that observed in detached leaves; at 14 days, the population sizes of $X$. citri in WT Carrizo citrange in undamaged, infiltrated tissues were approximately 100 -fold higher than in the transgenic plant. In fact, no bacterial growth was observed at 14 days after inoculation of transgenic Pineapple sweet orange (data not shown).

\section{Microscopy analyses reveal altered $X$. citri biofilm behavior and absence of leaf tissue damage on transgenic leaves.}

Because the lesions formed on transgenic leaves differed from those on WT plants, confocal scanning microscopy was used to better analyze the differences in multiplication of $X$.

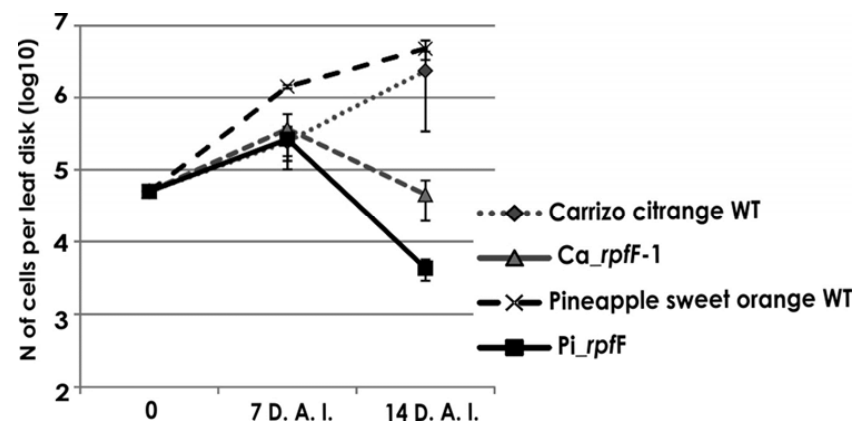

Fig. 4. Bacterial population analysis from Xanthomonas citri isolated from leaf disks away of lesion area. Serial dilution of isolated bacteria was performed at 7 and 14 days after inoculation for Carrizo citrange and Pineapple sweet orange wild-type (WT) and transgenic plants. Results are means of three repetitions. Bars indicate the standard deviation of the means. The $X$. citri growth observed at 14 days after inoculation in transgenic plants was significantly $(P<0.05)$ less compared with the WT. citri in these lesions. As noted above, in WT plants, lesions formed at the damaged site of inoculation were somewhat larger than more peripheral lesions. In contrast, lesions were formed only at the damaged site of inoculation in the transgenic plants. The differences in the size and appearance of the lesions were quite apparent when visualized by scanning electron microscopy (Fig. 5). Cells of $X$. citri inoculated into leaves of transgenic plants were not able to break through leaf tissues to emerge onto leaf surfaces, apparently because they exhibited relatively little growth except at sites of wounding of the leaf. To further explore the process of growth within tissues, we examined the spatial pattern of GFP fluorescent cells in erumpent lesions at this point of inoculation (Fig. 6A and B). Whereas cells of $X$. citri formed layers with a relatively uniform thickness in lesions on WT plants, the layer of cells in lesions on the transgenic leaves was much thicker but more spatially restricted to the discrete lesions formed on these plants (Fig. 6). Thus, although a much larger area of leaves of WT plants harbored biofilms of the pathogen, it was restricted to only the point of inoculation on transgenic leaves but formed a much thicker biofilm at that site. These differences in biofilm formation on WT and transgenic leaves observed at 7 days were even more accentuated when visualized at 14 days after inoculation. By this later time, most lesions on transgenic leaves could not be visualized because the thick biofilms that had formed interfered with the microscopy process. It remained apparent, however, that few cells were present adjacent to these sites of lesion formation in unwounded sites on the leaf (Fig. 5).

The results of the fluorescence microscopy of the leaf regions into which a GFP-marked strain of $X$. citri was injected suggested that growth of this pathogen occurred throughout the inoculated region in WT plants but was restricted to damaged sites in rpfF-expressing plants. Such visualization was unable to document differences in growth of the pathogen at those sites in which it apparently could multiply in these plants. Therefore, we quantified $X$. citri population sizes in excised disks of leaf tissue, including the region damaged during the infiltration process, at which the most prominent lesions subsequently occurred in all plants. Curiously, despite the obvious differences in the types of lesions which had formed, similar numbers of $X$. citri cells were recovered at a given sampling time after inoculation from the WT and $r p f F$-expressing plants (Fig. 7) compared with what was observed for whole plant leaves (data not shown). Thus, it appears that, although limited to sites of mechanical injury, $X$. citri could exhibit similar rates of growth in transgenic plants as in WT plants at such wound sites. The larger number of sites where lesions that formed in the WT plants might have reduced the growth of $X$. citri within a given lesion; however, in aggregate, similar overall amounts of bacterial multiplication occurred within a given tissue sample. These results suggest that factors present in the damaged tissues overcame the limitations of $X$. citri to grow in $r p f F$-expressing leaves. Such factors apparently do not occur in regions away from the inoculation site, where the bacterial populations in transgenic plants were significantly lower than in WT plants (Fig. 4).

\section{Downregulation of genes positively modulated by DSF in $X$. citri.}

Because we expected that the $r p f F$-expressing citrus plants would produce a variety of DSF species similar to that observed in $r p f F$-expressing grape (Lindow et al. 2014), and because $X$. citri was observed to have altered behavior in the transgenic citrus, we speculated that the DSF species produced by these plants were affecting cell-to-cell signaling in the pathogen. Thus, we assessed transcript abundance of a variety of genes 
whose transcription was previously shown to be dependent on DSF in $X$. citri (Guo et al. 2012) by qRT-PCR. In addition, transcripts of other genes contributing to symptoms of canker disease such as the T3SS that are also regulated by $r p f G$ (Gabriel 1999; Guo et al. 2012; Swarup et al. 1992) were assessed. Surprisingly, most of the genes that were known to be upregulated in the presence of DSF exhibited lower levels of expression in the $r p f F$-expressing citrus lines compared with the WT plant (Fig. 8). For example, genes involved in cell motility such as those conferring flagellar production and function (fliC and $f l i K$ ) and type IV pili (pilM) were downregulated in bacteria isolated from leaves of the transgenic plants compared with the WT plant (Fig. 8). Likewise, the transcripts of eng, encoding an endoglucanase, were also lower in abundance in cells of $X$. citri recovered from leaves of transgenic plants compared with that of the WT plant (Fig. 8). These results were more evident on both Carrizo citrange transgenic plants sampled 14 days after inoculation (Fig. 8A and B) but it was apparent in the transgenic Pineapple sweet orange cultivar when assessed both at 7 and 14 days after inoculation (Fig. 8C). At most sample times, the abundance of transcripts of gumB were lower in abundance in transgenic Carrizo citrange and Pineapple sweet orange plants than in the corresponding WT plants. Given that watersoaking lesions were not observed during infection of the transgenic plants by X. citri, it is noteworthy that most of the genes involved in T3SS that contribute to such symptoms and which are regulated by $r p f G$ (Guo et al. 2012) were downregulated in the transgenic plants compared with the WT plant. In our work, we investigated the modulation of $h r p b X C t, h r p B 2$, and $p t h A$. Although $h r p b X C t$, a regulator of T3SS, was not modulated in $\mathrm{Ca}$ rpffF-1 at 7 and 14 days after inoculation (Fig. 8A), in Ca_rpfF-2, it was significantly repressed at both time points (Fig. 8B). hrpB2 did not show significant change in expression in either Carrizo citrange transformant at 7 days after inoculation but it was repressed in $\mathrm{Ca} \_r p f F-2$ at 14 days after inoculation (Fig. 8A and B). However, pthA, a virulence determinant, was negatively modulated in both transgenic Carrizo citrange plants at 14 days after inoculation (Fig. 8A and B). In Pineapple sweet orange transgenic plants, on the other hand, downregulation of all genes related to T3SS was observed both at 7 and 14 days after inoculation (Fig. 8C). It seems likely that the repression of this suite of virulence genes in $X$. citri in the $r p f F$-expressing citrus cultivars is linked to their apparent reduced susceptibility to infection by this pathogen. Although the expression of only a subset of the genes in X. citri was assessed in these transgenic plants, it is noteworthy that all those genes examined, whose expression is lower in $X$. citri when $r p f F, r p f C$, and $r p f G$ are disrupted, also exhibited lower apparent expression in $r p f F$-expressing transgenic plants (Table 1), suggesting that one or more factors present in these plants interfered with DSF-mediated QS and, hence, with the virulence of this pathogen.

Given that the process of DSF signaling and the fatty acids serving as DSF species appear to differ between $X$. campestris and Xylella fastidiosa (Beaulieu et al. 2013) and, hence, by association with Xanthomonas citri, it appeared unlikely that the DSF species produced in the transgenic plants harboring the rpfF from Xylella fastidiosa would prove to be inducers of gene expression in Xanthomonas citri. Instead, the suppression of DSF-dependent genes in X. citri suggested that an antagonist of DSF signaling might be present in the transgenic plants. To test this conjecture, the $X$. campestris pv. campestris-based DSF biosensor (Beaulieu et al. 2013) was used to assess the biological activity of xylem sap extracts from the transgenic citrus. Indeed, no evidence for inducers of gene expression was observed in such extracts. However, strong evidence was
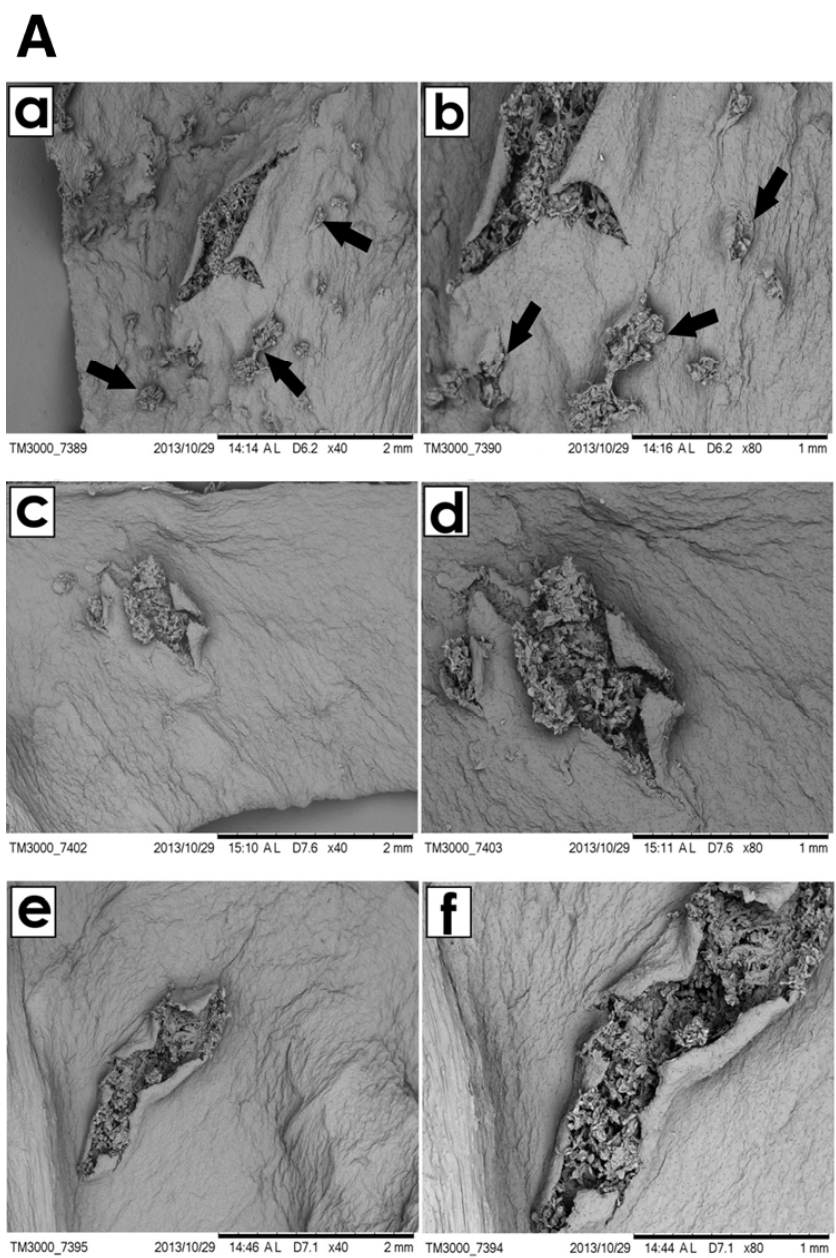

B
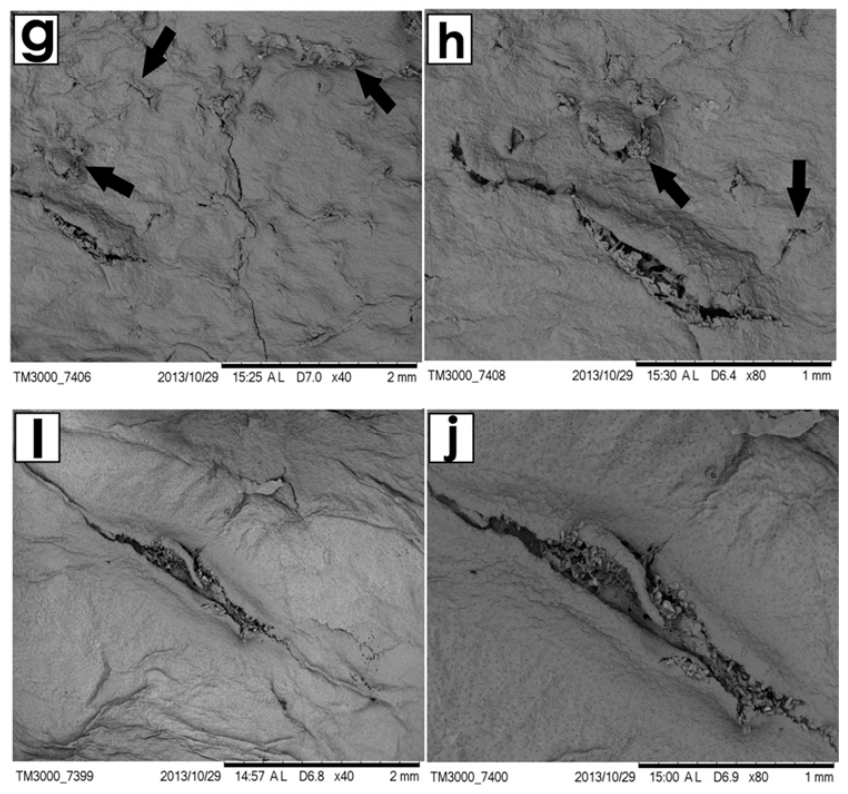

Fig. 5. Scanning electron micrographs of canker lesions. Xanthomonas citri_GFP was infiltrated in leaves of wild-type (WT) and transgenic plants and evaluated at 14 days after inoculation. A, Carrizo citrange and $\mathbf{B}$, Pineapple sweet orange plants. WT plants are represented in $\mathbf{a}$ and $\mathbf{b}$ (Carrizo citrange) and $\mathbf{g}$ and $\mathbf{h}$ (Pineapple sweet orange). Black arrows indicate the pustules formed on WT leaves. The biggest injury corresponds to the inoculation point on the leaves. Transgenic Ca_rpfF-1 is represented in $\mathbf{c}$ and $\mathbf{d}, \mathrm{Ca} \_r p f F-2$ in $\mathbf{e}$ and $\mathbf{f}$, and $\mathrm{Pi} \_r p f F$ in $\mathbf{g}$ and $\mathbf{h}$. Magnitudes used were $\times 40(\mathbf{a}, \mathbf{c}, \mathbf{e}, \mathbf{g}$, and $\mathbf{i})$ and $\times 80(\mathbf{b}, \mathbf{d}, \mathbf{f}, \mathbf{h}$, and $\mathbf{j})$. 
obtained that the signaling that would otherwise have been conferred by 2(Z)-11-methyldodecenoic acid was suppressed in the presence of molecules present in the sap of the transgenic citrus but not in the sap of WT plants (Fig. 9). In contrast, there was a significant induction of PhoA activity in a Xylella fastidiosa-based DSF biosensor (Beaulieu et al. 2013) exposed to the sap from the transgenic plants (Fig. 10), indicating that the DSF from transgenic plants is antagonistic to QS in Xanthomonas citri but stimulates QS in Xylella fastidiosa.

\section{DISCUSSION}

The ectopic expression of rpfF from $X$. fastidiosa in citrus genotypes in an effort to reduce their susceptibility to CVC inadvertently and unexpectedly decreased their susceptibility to citrus canker disease caused by Xanthomonas citri. Because the main effect of the expression of $r p f F$ in the plant would be to alter the pattern of unsaturated fatty acid production, we presume that the altered pathogen behavior in the transgenic plants was due to a disruption of their DSF-medi-
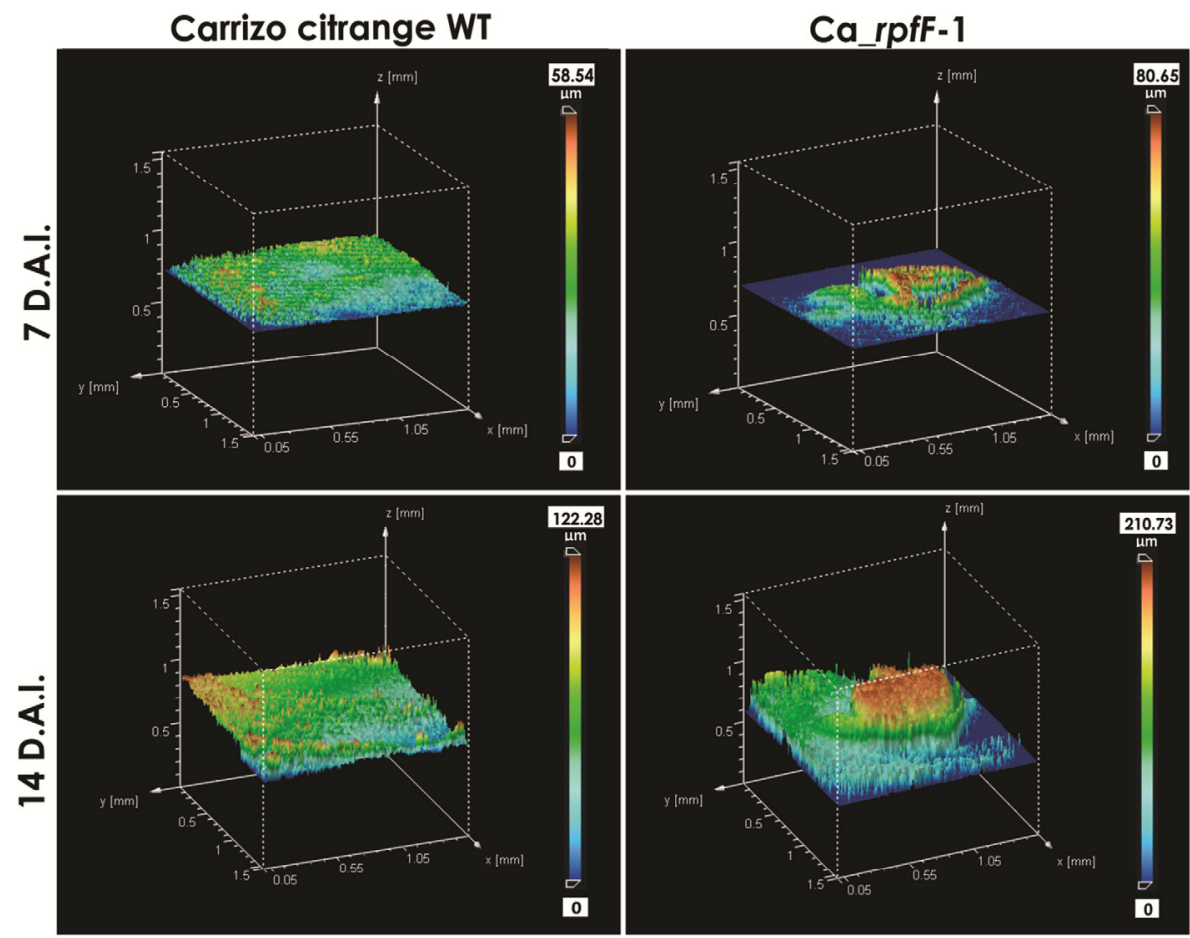

Ca_rpfF-2

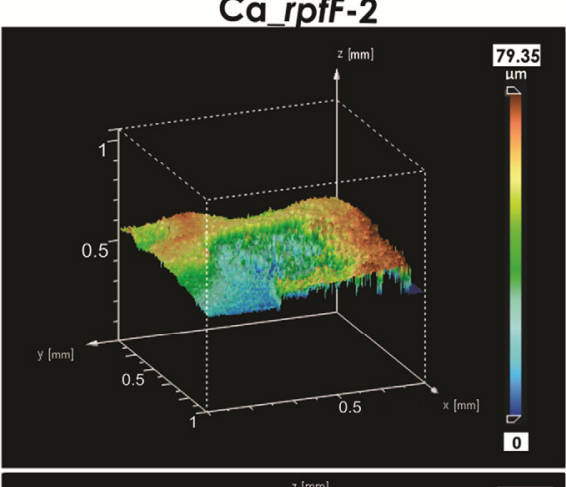

Pineapple sweet orange WT

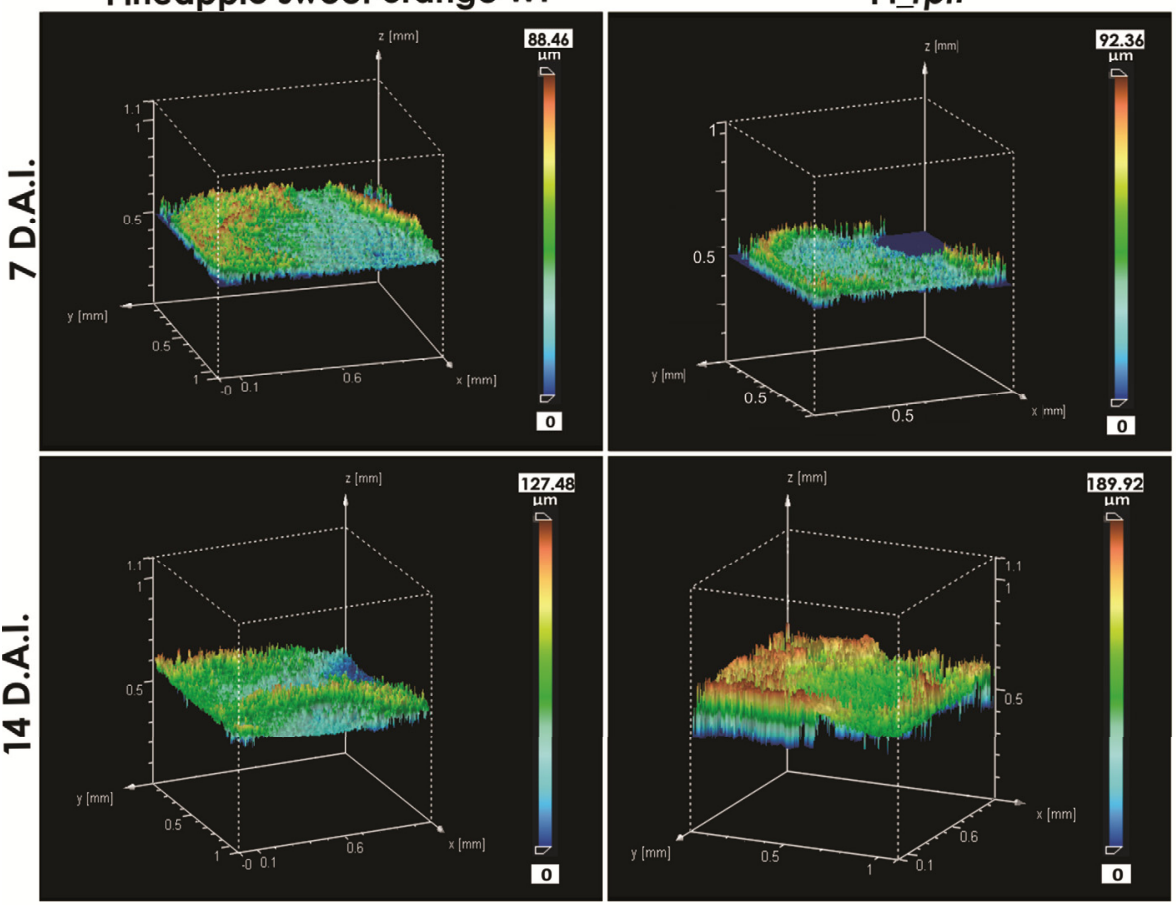

Fig. 6. Three-dimensional reconstruction of biofilm topography from confocal scanning laser microscopy. Xanthomonas citri_GFP was infiltrated in leaves of wild-type (WT) and transgenic plants and evaluated at 7 and 14 days after inoculation (D.A.I.). Bacterial biofilm layers are represented by different colors and total biofilm is expressed by the color scales, where blue and red tones represent the thinnest and thickest, respectively. A, Biofilm topography on Carrizo citrange WT and transgenic leaves. B, Biofilm topography on Pineapple sweet orange WT and transgenic leaves. 
ated patterns of gene expression. Although the various DSFlike molecules present in these transgenic plants are not yet fully elucidated, evidence was obtained that at least one may antagonize the normal DSF-dependent signaling process in X. citri.

Although the process of DSF-dependent QS in X. citri has not been as thoroughly investigated as in other Xanthomonas spp. such as $X$. campestris, we presume that it shares considerable similarity to that of $X$. campestris, and likely differs substantially from that of Xylella fastidiosa. Thus, we might expect that gene expression in Xanthomonas citri is most responsive to signal molecules such as 2(Z)-11-methyldodecenoic acid (DSF) and 2(Z)-dodecenoic acid (BDSF), as are $X$. campestris strains (He et al. 2010; Ryan and Dow 2011), while being relatively unresponsive to molecules such as $2(Z)$-tetradecenoic acid (XfDSF), to which Xylella fastidiosa is preferentially responsive (Beaulieu et al. 2013). Indeed, we found no evidence of induction of the DSF-dependent eng gene in Xanthomonas campestris by extracts of xylem sap from transgenic

A
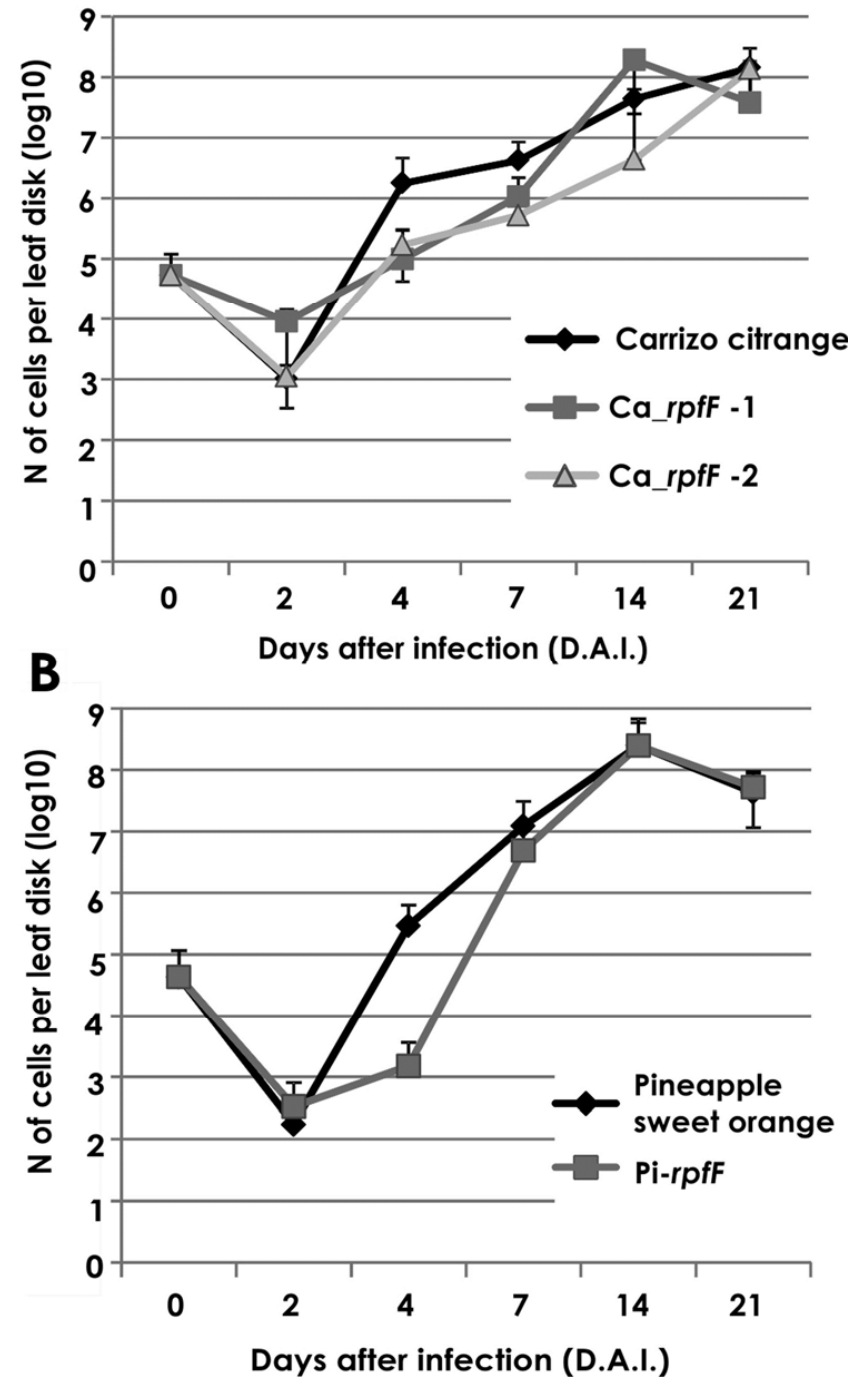

Fig. 7. Xanthomonas citri_GFP growth curves in detached leaves. Leaves were infiltrated with $10^{4}$ cells and growth was evaluated at 2, 4, 7, 14, and 21 days after inoculation. A, Growth curve of $X$. citri_GFP in Carrizo citrange wild-type (WT) and transgenic plants. B, Growth curve of $X$. citri_GFP in Pineapple sweet orange WT and transgenic plant. The standard deviation bar represents the mean of three repetitions. No statistically significant difference was observed. plants but did find evidence of the suppression of the induction of eng by such extracts in the presence of DSF itself (Fig. 9). The nature of the compound or compounds responsible for such antagonism remains unknown but it seems most likely
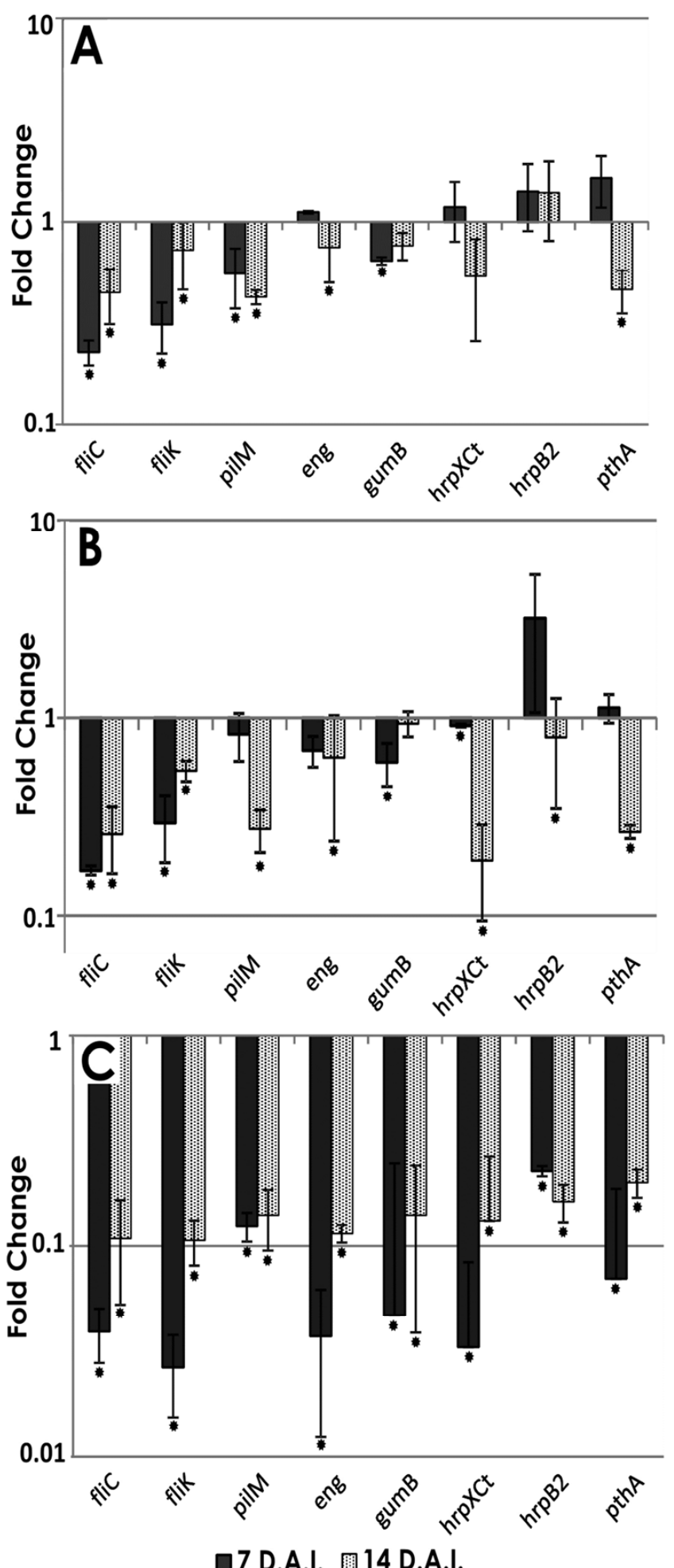

Fig. 8. Relative quantification of genes responsive to diffusible signal factor in Xanthomonas citri. Gene expression was evaluated for $\mathbf{A}, \mathrm{Ca} r r p f F-1 ; \mathbf{B}$, $\mathrm{Ca} \_r p f F-2$; and $\mathbf{C}, \mathrm{Pi} r p f F$ in relation to wild-type (WT) at 7 and 14 days after inoculation (D.A.I.). Results are means of three independent experiments. Bars indicate the standard deviation of the means; * indicates significant difference $(P<0.05)$ between the mean values obtained for each gene compared with the WT. 
that they are also fatty acids. Some evidence for such a phenomenon has also been observed in the DSF signaling system of grape strains of Xylella fastidiosa, where certain trans-unsaturated fatty acids were found to block induction otherwise conferred by XfDSF (Ionescu et al. 2013).

The reduced susceptibility of the $r p f F$-expressing citrus plants may be due, in part, to reduced motility of Xanthomonas citri in and on plants. Among the genes whose expression was reduced the most in cells of the pathogen recovered from the transgenic plants compared with the WT plants were those involved in motility, including genes encoding the flagella itself and others involved in flagellar function (Table 1). Although it was not possible to directly assess cell motility within the plant, such strong repression of these genes would imply that the cells would have exhibited greatly reduced motility. The role of motility in the pathogenesis of plants by bacteria is not well understood. Studies of Pseudomonas syringae reveal that nonmotile mutants are still virulent to plants and symptom development remains similar to that of the WT strain in various hosts when they are infiltrated into tissues (Panopoulos and Schroth 1974). In contrast, the incidence of infection of plants when such nonmotile mutants are topically applied to leaves is greatly reduced (Panopoulos and Schroth 1974). Additionally, gumB is also downregulated and, because this gene is important for the sliding movement (Malamud et al. 2011, 2013), the thicker biofilm observed on transgenic plants could be due, in part, to the absence of this sliding ability.

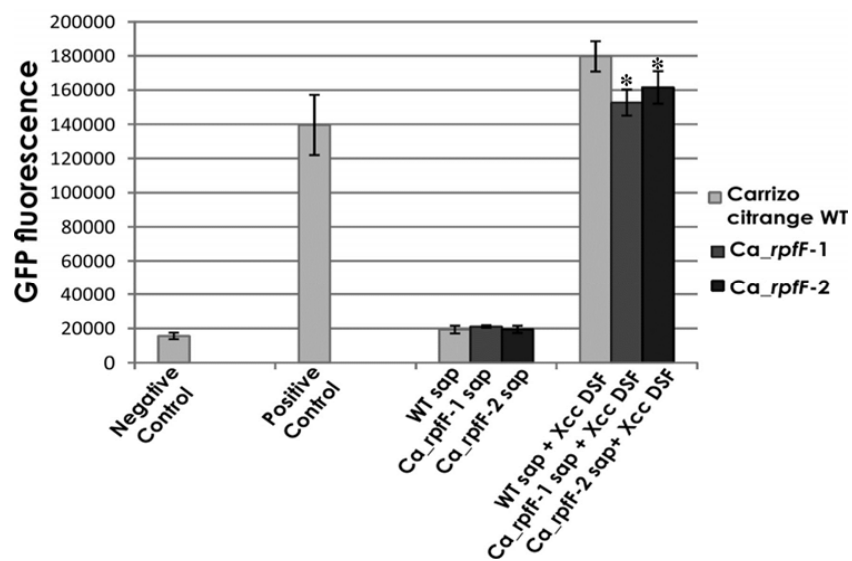

Fig. 9. Green fluorescent protein (GFP) fluorescence triggered by Xanthomonas campestris biosensor cells. Negative control represents untreated cells. Positive control represents cells treated only with XccDSF. Treatments only with sap without diffusible signal factor (DSF) shows no GFP emission from the sensor while treatments with sap plus DSF from transgenic plants significantly decreased the emission of GFP. Results are means of three repetitions. Bars indicate the standard deviation of the means; * indicates significant difference $(P<0.05)$ between the mean values obtained for each gene compared with the WT.
The apparent virulence of $X$. citri cells within the apoplast of $r p f F$-expressing plants also seemed to be much lower than that of WT plants. Apparently, relatively little spreading of $X$. citri cells occurs after infiltration into leaves, because the multiplication of GFP-marked strains of this pathogen after infiltration of leaves resulted in apparently discrete microcolonies after introduction of relatively low numbers of cells in WT plants (Fig. 3). We presume that such microcolonies originated from individual cells originally deposited within the intercellular spaces. Equal numbers of cells were also introduced into the transgenic plants; therefore, the lack of apparent microcolony development was taken as evidence of their lack of substantial multiplication in these hosts. This was confirmed by the finding of reduced population of $X$. citri in areas of infiltrated leaves of RpfF-expressing plants away from the damage point of inoculation, where lesions invariably formed in WT plants (Fig. 4). Apparently, a variety of virulence traits such as those in the T3SS were sufficiently suppressed in these transgenic plants that little growth of the pathogen was possible. This is further substantiated by the lack of apparent watersoaking in areas infiltrated with cells of $X$. citri in the $r p f F$-expressing plants. Other studies have suggested that watersoaking contributes to the growth of plant-pathogenic bacteria in plant tissues, presumably by aiding the liberation and mobility of nutrients from plant cells (Brunings and Gabriel 2003; Popham et al. 1993).

It was very curious that the apparent suppression of virulence of $X$. citri in the $r p f F$-expressing citrus plants was abolished in the area around the point of inoculation. The infiltration of leaf tissues with a needle invariably leads to a small

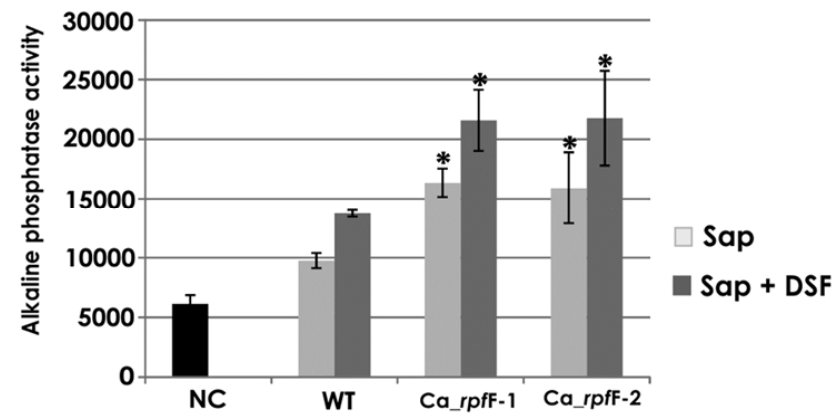

Fig. 10. Alkaline phosphatase (AP) activity exhibited by cells of a Xylella fastidiosa diffusible signal factor (DSF) biosensor. The sap from wild-type (WT) and transgenic plants was tested for induction of expression of the phoA gene under the control of the DSF-induced $h x f A$ promoter, by measuring the AP activity. Sap alone (gray bars) or sap to which $3 \mu \mathrm{M} X f \mathrm{DSF}$ had been added (dark bars) was tested. Negative control (NC) corresponds to AP activity from cells cultured on periwinkle gelrite medium. Vertical bars indicate the standard deviation of the means; * indicates a significant difference $(P<0.05)$ between the mean values obtained for the transgenic plants compared with the WT.

Table 1. Relative expression of Xanthomonas citri genes responsive to diffusible signal factor measured ${ }^{\mathrm{a}}$

\begin{tabular}{|c|c|c|c|c|c|c|c|c|c|c|}
\hline Locus tag & $\begin{array}{l}\text { Gene } \\
\text { name }\end{array}$ & $r p f C^{-}$ & $r p f F^{-}$ & $r p f G^{-}$ & $\begin{array}{c}\text { Ca_rpfF-1 } \\
7 \text { DAI }\end{array}$ & $\begin{array}{c}\text { Ca_rpfF-1 } \\
14 \text { DAI }\end{array}$ & $\begin{array}{c}\text { Ca_rpfF-2 } \\
7 \text { DAI }\end{array}$ & $\begin{array}{c}\text { Ca_rpfF-2 } \\
\text { 14 DAI }\end{array}$ & $\begin{array}{c}\text { Pi_rpfF } \\
7 \text { DAI }\end{array}$ & $\begin{array}{r}\text { Pi_rpfF } \\
\text { 14 DAI }\end{array}$ \\
\hline XAC0612 & eng & Down & Down & Down & $\mathrm{nr}$ & Down & $\mathrm{nr}$ & Down & Down & Down \\
\hline XAC1975 & $\mathrm{fliC}$ & Down & Down & Down & Down & Down & Down & Down & Down & Down \\
\hline XАC1949 & fliK & Down & Down & Down & Down & Down & Down & Down & Down & Down \\
\hline XAC2585 & gumB & Down & Down & - & Down & $\mathrm{nr}$ & Down & $\mathrm{nr}$ & Down & Down \\
\hline XAC0408 & hrpB2 & Down & $\mathrm{nr}$ & Down & $\mathrm{nr}$ & $\mathrm{nr}$ & $\mathrm{nr}$ & $\mathrm{nr}$ & Down & Down \\
\hline XAC1266 & $h r p X c t$ & Down & Down & $\mathrm{nr}$ & $\mathrm{nr}$ & $\mathrm{nr}$ & Down & Down & Down & Down \\
\hline $\mathrm{XACa} 022$ & pthA & - & - & - & $\mathrm{nr}$ & Down & $\mathrm{nr}$ & Down & Down & Down \\
\hline XAC3385 & pilM & Down & Down & $\mathrm{nr}$ & Down & Down & $\mathrm{nr}$ & Down & Down & Down \\
\hline
\end{tabular}

${ }^{\mathrm{a}} \mathrm{DAI}=$ days after inoculation, Down = downregulated, $\mathrm{Nr}=$ nonresponsive, and - = no information available. References: $r p f C^{-}$and $r p f F^{-}$, Guo et al. 2012 and Malamud et al. 2011; $r p f F^{-}$, Guo et al. 2012; and all others, this work. 
region of damage where the needle contacts the leaf, although apparently no damage is conferred elsewhere to the leaf by the introduction of fluids containing bacterial cells which then spread in the intercellular spaces away from this site of introduction. It was noteworthy that, whereas erumpent pustules formed throughout the region infiltrated with cells of $X$. citri in the WT plants, such pustules formed only at sites of damage in the rpfF-expressing plants (Figs. 2 and 3). In fact, such lesions were apparently coincident with that damaged tissue in such plants. We speculate that this damage in some way abrogated the need for expression of various virulence factors by $X$. citri. Thus, those cells in which such virulence factors were suppressed in the transgenic plants presumably would have been able to incite disease symptoms at such sites but only at such sites. Apparently, the likelihood of disease initiation in the absence of such localized damage would have been greatly reduced elsewhere on the plant, as indicated by the reduced number of lesions away from the damaged point of inoculation. It is possible that damage locally triggered an induction of jasmonic acid (JA), a well-known regulator of plant responses to such stresses (Dennes et al. 2011). Given that antagonistic relationships between JA-mediated signaling and salicylic acid-mediated signaling are known to be common in plants (Niki et al. 1998), it is possible that the mechanical damage of inoculation reduced host defenses that normally require the function of virulence genes such as hrp to suppress such defense reactions. In such a setting, $X$. citri might have been able to elicit disease symptoms despite the suppression of the T3SS which occurred in the $r p f F$-expressing plants. However, it was clear that $X$. citri was capable of robust growth at such localized sites of damage because its population size at such sites in the transgenic plants was usually as large as that occurring over larger areas of infiltrated tissues of WT plants, despite the fact that little growth appeared to occur away from such sites of damage (Figs. 4 and 7).

The reduced susceptibility of $r p f F$-expressing citrus to $X$. citri observed here appears to be due to altered pathogen behavior that could have influenced the disease process in two different ways. Disease control by so-called "pathogen confusion" has been conferred by either amplification or suppression of cell-density-dependent signaling in plant-pathogenic bacteria. The production of AHL signal molecules in transgenic tobacco plants increases their resistance to soft rot disease symptoms incited by Erwinia carotovora (Mäe et al. 2001). In such plants, this pathogen expressed virulence traits such as extracellular enzymes soon after inoculation, before large population sizes would have developed. Because the extracellular enzymes needed for the disease symptoms are normally produced only upon the accumulation of the AHL signal as pathogen populations increase, it was proposed that the enhanced resistance of these AHL-producing plants was due to an earlier recognition of the virulence factors by the plant, triggering successful defense reactions (Mäe et al. 2001). Thus, it has been proposed that plants might be made more resistant to pathogens by overcoming their "stealthy" patterns of expression of virulence factors by triggering their production by the omnipresence of signal molecules needed for their production (Mäe et al. 2001). No evidence for premature induction of such virulence factors in $X$. citri in the rpfFexpressing citrus was seen in this study. In fact, such virulence factors appear to be suppressed in the transgenic plants compared with the WT plant. As such, the process by which the susceptibility of the $r p f F$-expressing citrus was reduced is more likely similar to that conferred by the production of an AHL acylase in transgenic plants in studies described previously (Dong et al. 2001). The destruction of the AHL signal molecule needed for induction of extracellular enzymes of $E$. carotovora by this enzyme in the transgenic plants apparently prevented the accumulation of sufficient signal molecules to induce virulence factors needed for symptoms development. Given that the virulence of $X$. citri is strongly dependent on DSF-mediated QS, future strategies of enhanced production of compounds that can antagonize this process appear attractive as a strategy for disease control.

\section{MATERIALS AND METHODS}

\section{Construction of $r p f F$ vector}

\section{and $A$. tumefaciens transformation.}

The entire $r p f F$ gene was amplified from the Xylella fastidiosa 9a5c strain genome using Taq Platinum (Invitrogen) with the primer pairs F: 5' AGAGGTACCAATGTCCGCTGTACAT $3^{\prime}$ containing a KpnI restriction site, and R: 5' AGCGGATCCT GCTCAGTTTTTTAGTG 3' containing a BamHI restriction site. The expected size of the amplicon was $900 \mathrm{bp}$. After isolation of the fragment from a $1 \%$ agarose gel, it was purified using a GFX PCR DNA and gel band purification kit (Amersham Biosciences) and cloned into pGEM-T Easy (Promega Corp.). This plasmid was transformed into Escherichia coli DH5 $\alpha$ competent cells and transformants were selected in Luria-Bertani medium containing ampicillin at $100 \mu \mathrm{g} / \mathrm{ml}$. Plasmids were isolated from $E$. coli cells using an Invisorb Spin Plasmid Mini Two kit (Invitek) and sequenced following the manufacturer's instructions using a BigDye Terminator cycle sequencing Ready Reaction DNA sequencing kit (v 3.0), and the resulting products were separated on an ABI 3730 automatic sequencer (Applied Biosystems).

The quality of the cloned DNA fragment was confirmed by comparison with the $X$. fastidiosa database using BlastN and BlastX. Plasmid-containing sequences that exhibited $100 \%$ identity with the expected nucleotide sequences were cleaved with KpnI and BamHI (Invitrogen) for directional cloning into pRT101 harboring a Cauliflower mosaic virus 35S promoter and a $3^{\prime}$ poly A region. The presence of the target gene was confirmed by PCR using specific primers for $r p f F$ as well as the entire cassette; the $35 \mathrm{~S}$ forward primer was $35 \mathrm{~S} \mathrm{~F}: 5^{\prime} \mathrm{ACA}$ CTCTCGTCTACTCCAAG $3^{\prime}$ and the reverse primer was $\mathrm{R}$. Plasmids were then sequenced to confirm the correct orientation of the target gene. The resultant cassette was digested with HindIII and cloned into pCambia 2301 at the polylinker, maintaining the GUS reporter gene to yield $r p f F$ pCambia2301. A. tumefaciens EAH105 was transformed with rpfFpCambia2301 by a heat-shock method and cells were selected on YEP medium (An et al. 1988) containing kanamycin and rifampicin $(50 \mu \mathrm{g} / \mathrm{ml}$ each). Transformants were tested by PCR using primers designed for $r p f F$. A positive colony was grown in $10 \mathrm{ml}$ of YEP containing kanamycin and rifampicin for $16 \mathrm{~h}$. A 3-ml aliquot was then added to $50 \mathrm{ml}$ of liquid YEP and grown until an optical density at $600 \mathrm{~nm}\left(\mathrm{OD}_{600}\right)=0.4$. This culture was centrifuged and $\mathrm{OD}_{600}$ corrected to 1.0 with Murashige and Skoog (MS) basal medium for inoculation of epicotyl segments.

\section{Citrus transformation.}

Seed of Pineapple sweet orange ( $C$. sinensis L. Osb.) and Carrizo citrange $(C$. sinensis (L.) Osb. $\times$ Poncirus trifoliate (L.) Raf.) were germinated in half-strength MS basal medium (Murashige and Skoog 1962), supplemented with myo-inositol at $100 \mathrm{mg} / \mathrm{liter}$ and sucrose at $30 \mathrm{~g} / \mathrm{liter}$ and solidified with agar (PhytoTechnology Laboratories) at $7 \mathrm{~g} /$ liter, and used as an explant source. Dark-green epicotyls were harvested and cut into 1-cm-long segments to expose the cambial ring. These segments were incubated in liquid MS basal medium supplemented with indole acetic acid at $100 \mathrm{mg} /$ liter before emersion in suspensions of A. tumefaciens (rpfFpCambia2301) for $5 \mathrm{~min}$, 
and dried on sterile paper towels. Dried explants were then placed on solid MT co-cultivation medium (MS salts, tiamine at $1 \mathrm{~g} /$ liter, piridoxine at $5 \mathrm{~g} /$ liter, nicotinic acid at $5 \mathrm{~g} / \mathrm{liter}$, glycine at $20 \mathrm{~g} /$ liter, myo-inositol at $100 \mathrm{mg} / \mathrm{liter}$, sucrose at 30 $\mathrm{g} / \mathrm{liter}$, benzylaminopurine at $1 \mathrm{mg} / \mathrm{liter}$, and agar at $6.0 \mathrm{~g} / \mathrm{liter}$ ) in the dark at $24^{\circ} \mathrm{C}$ for 3 days before being transferred to MT selection medium (MT co-cultivation with kanamycin at 100 $\mathrm{mg} / \mathrm{liter}$ and cefotaxim at $500 \mathrm{mg} / \mathrm{liter}$ ). Explants in MT selection medium were cultured in the dark at $28^{\circ} \mathrm{C}$ until development of shoots. MT plates were then incubated in the light (cycle of $16 \mathrm{~h}$ of light and $8 \mathrm{~h}$ of darkness using cool white fluorescent light $\left[75 \mathrm{lmol} \mathrm{s}^{-1} \mathrm{~m}^{-2}\right]$ ) until shoots were well developed. A small piece of each shoot was excised and incubated in $500 \mu \mathrm{l}$ of phosphate buffer containing 5-bromo-4chloro-3-indolyl- $\beta$-D-glucuronide for $16 \mathrm{~h}$ at $37^{\circ} \mathrm{C}$ to test GUS activity. Samples were then suspended in $500 \mu \mathrm{l}$ of a solution of $1: 1$ acetic acid/ethanol until they turned white. Shoots that became blue, indicative of GUS activity, were considered positive. Transformed Pineapple sweet orange shoots were micrografted onto Carrizo citrange rootstocks and Carrizo citrange shoots were grafted onto Sunki rootstocks and maintained in $4 \mathrm{ml}$ of solid MT medium until development of roots and leaves. Plants carrying the transgene will be referred to as Ca-rpfF for Carrizo citrange and Pi-rpfF for Pineapple sweet orange. Controls were done by the same method but without the A. tumefaciens dipping step.

\section{Analysis of transformed plants.}

Before transfer to the greenhouse, plants were analyzed by PCR using total DNA as template and using specific primers for $r p f F$ to confirm the presence of the target gene. Plants that contained the fragment of the size expected for the $r p f F$ gene were subjected to a second PCR analysis using cDNA as template. RNA was extracted from four leaves from the top of each elite plant using TRIzol Isolation Reagents (Life Technologies) and treated with RNAse-Free DNAse (Qiagen). cDNAs from control and transgenic leaves were then reverse transcribed using oligo-dT. as described in the RevertAid first strand cDNA synthesis kit (Thermo Scientific). Positive plants after this step were again evaluated for the presence of cDNA corresponding to the target gene by qPCR assay using specific primers for $r p f F$ designed using the Primer Express 3.0 software (Applied Biosystems). Ubiquitin was used as an internal control and two qRT-PCRs were performed on each mRNA sample using SYBR-green mix and the universal conditions of amplification provided by the 7500 System (Applied Biosystems). Dissociation curves were analyzed in every amplification mixture; when more than one amplicon was observed, the qRT-PCR conditions were changed to obtain a single dissociation product. The results were analyzed by the 7500 System software (Applied Biosystems) using the relative quantification method. Buds of all plants positive in all three tests were grafted onto lemon rootstocks. GUS assays were performed as described above to detect chimeras; only positive buds were used for further screening for susceptibility to Xanthomonas citri.

\section{$X$. citri_GFP infiltration assays.}

Infiltration assays were performed in Carrizo citrange and Pineapple sweet orange WT and transgenic leaves using $X$. citri 306 harboring a constitutively expressed GFP marker gene (referred as X. citri_GFP; provided by A. A. Vojnov, CONICET [National Scientific and Technical Research Council-Argentina]) (Rigano et al. 2007). X. citri_GFP was grown overnight in liquid NBY nutrient medium $(0 . \overline{5} \%$ peptone, $0.3 \%$ meat extract, $0.2 \%$ yeast extract, $0.2 \% \mathrm{~K}_{2} \mathrm{HPO}_{4}$, and $0.05 \% \mathrm{KH}_{2} \mathrm{PO}_{4}$ ), containing ampicillin at $100 \mu \mathrm{g} / \mathrm{ml}$. This inoculum was diluted to an $\mathrm{OD}_{600}=0.01$ in phosphate-buffered saline (PBS) buffer. The culture used to infiltrate detached and whole plant leaves was also plated to determine bacteria population. Three independent experiments were performed in which $100 \mu \mathrm{l}$ of a suspension of $10^{4} \mathrm{CFU} / \mathrm{ml}$ was injected at five different points in a given Carrizo citrange leaf and at three different points for a Pineapple sweet orange leaf. Three leaves of similar age were chosen for a given experiment. Symptoms were evaluated 7 and 14 days after infiltration. Microscopic analysis of the lesion was done using an Olympus MVX10 (U-MGFPHQ filter) at a magnification of $\times 16$. Plants were also spray-inoculated with a suspension of $X$. citri at $10^{6}$ cells $/ \mathrm{ml}$ until leaves were wetted. Symptoms were evaluated 7 and 14 days after inoculation. Lesions were imaged to compare symptomatology at both time points

\section{Confocal scanning laser and scanning electron microscope analysis.}

Leaves of plants were infected by infiltration with a $10^{4}$ CFU/ml suspension of GFP-labeled WT X. citri. Lesion development was monitored with a confocal laser scanning microscope (TCS-SP5 II; Leica), using the 488-nm laser and emission filters TD (triple-dichroic 488-543-633) 7 and 14 days after inoculation. Leaf segments of approximately $1 \mathrm{~cm}^{2}$ that contained the lesion formed at the point of inoculation were cut from the leaves and mounted on the adaxial leaf surface under glass coverslips. The three-dimensional (3D) images were obtained by overlaying and aligning several horizontal confocal sections of $1.2 \mu \mathrm{m}$. The assay was performed in triplicate. Images were prepared as multichannel and 3D projections using the program LAS-AF, version 2.6.0.7266, to describe the spatial distribution of bacteria within the biofilms as well as differences in biofilm thickness and architecture. All images were done using scaling factor of 1.4.

Scanning electron microscopy analyses were done with leaves infiltrated with $X$. citri at 14 days after inoculation. Lesions were excised from WT and transgenic leaves and incubated at room temperature for $2 \mathrm{~h}$ in Karnovsky buffer $(2.5 \%$ glutaraldehyde and $2.5 \%$ paraformaldehyde in $0.1 \mathrm{M}$ sodium cacodylate buffer, $\mathrm{pH}$ 7.2), and samples were double washed for 5 min in the same buffer. For dehydration, samples were incubated $10 \mathrm{~min}$ in an ascending series of acetone solutions (50, 70, 90, 95, and 100\%). Dehydration was concluded in Critical Point Dryer Balzers CPD030, fixed on aluminum supports with double-sided carbon tape, and coated with gold in "Sputter Coater" Balzers SCD050. The material was examined and photographed in a scanning electron microscope (Hitachi TM3000).

\section{Bacterial growth in leaves.}

Bacterial growth in leaves was assessed by plating serial dilutions of bacteria recovered from leaf discs containing lesions formed at the point of inoculation of leaves 4, 7, 14, and 21 days after inoculation. A punch was used to excise lesion areas. Discs were homogenized in small tubes containing $1 \mathrm{ml}$ of PBS buffer and two glass beads. The suspensions were serially diluted and plated on NBY agar medium containing the appropriate antibiotic. At each time point, samples were determined from three replicate samples and each experiment was done three times. Similar sampling was performed on leaf discs taken at least $6 \mathrm{~mm}$ away from the point of inoculation.

\section{$X$. citri gene expression in plants.}

Gene expression in $X$. citri was assessed in leaves infiltrated with this pathogen in three independent experiments. All lesions of each leaf were collected using a round punch $(6 \mathrm{~mm}$ in diameter) 7 and 14 days after inoculation. A set of primer pairs 
Table 2. Gene names and primer sequences used in this work

\begin{tabular}{|c|c|c|c|}
\hline Gene number & Gene name & Primer sequence $5^{\prime}-3^{\prime a}$ & Size of amplicon (bp) \\
\hline \multirow[t]{2}{*}{ UBIQ CAS-PT-300961 } & ubiquitin & $\begin{array}{l}\text { F - TTCGTCAGTTGACTAATCCT } \\
\text { R - GTTGCTGTGTTGACTGTG }\end{array}$ & 100 \\
\hline & $35 \mathrm{~S}$ & F- ACACTCTCGTCTACTCCAAG & \\
\hline XF1115 & $r p f F$ & $\begin{array}{l}\mathrm{F}_{c}-\text { AGAGGTACCAATGTCCGCTGTACAT } \\
\mathrm{R}_{\mathrm{c}}-\text { AGCGGATCCTGCTCAGTTTTTTAGTG }\end{array}$ & 900 \\
\hline XF1115 & $r p f F$ & $\begin{array}{l}\mathrm{F}_{\mathrm{qPCR}} \text { - TCGGCAGCAAATCACTCCGAACTA } \\
\mathrm{R}_{\mathrm{qPCR}}-\text { CAGCACAGCTTTGAGTGCTCAGTT }\end{array}$ & 100 \\
\hline XAC1975 & fliC & $\begin{array}{l}\text { F - TCAAGCAGCTGACCTCTGAAATC } \\
\text { R - GCGCCGACCTGGAACAG }\end{array}$ & 100 \\
\hline XAC1949 & $f l i K$ & $\begin{array}{l}\mathrm{F}-\text { GGCTGCGCGAAATGCT } \\
\mathrm{R}-\text { TGCCCGCCGAATTCTG }\end{array}$ & 100 \\
\hline XCC2454 & $\operatorname{gum} B$ & $\begin{array}{l}\text { F - CATGGTCAACGGGCAAAAG } \\
\text { R - AGATCTCAGGATCCGGATTGG }\end{array}$ & 100 \\
\hline XAC0408 & hrpB2 & $\begin{array}{l}\text { F - CCATCGCCGAGCATATCG } \\
\text { R - ATGGTCAGCTCGTGCATCAA }\end{array}$ & 100 \\
\hline XAC1266 & hrpXct & $\begin{array}{l}\text { F - GACGTCGACGGTGTGCAA } \\
\text { R - CTCTGAAAGCCATCGAAAAAATC }\end{array}$ & 100 \\
\hline XAC0612 & engXCA & $\begin{array}{l}\text { F - CGTATTCCGAAGCGCAATG } \\
\text { R - TGCGGCTCGTTCTTCAGAT }\end{array}$ & 100 \\
\hline XAC3385 & pilM & $\begin{array}{l}\text { F - GCGTGAAGGGCTTGTCAACT } \\
\text { R - GGTAAAAGCCCCACGGTAACT }\end{array}$ & 100 \\
\hline \multirow[t]{2}{*}{ XAC0022 } & pthA-1 & $\begin{array}{l}\mathrm{F} \text { - CACCTCAGCGTCGAATTCG } \\
\mathrm{R} \text { - TCCTATGATCGGCGAGTACGT }\end{array}$ & 100 \\
\hline & $16 \mathrm{~S}$ & $\begin{array}{l}\mathrm{F} \text { - CCGGATTGGAGTCTGCAACT } \\
\mathrm{R} \text { - ACGTATTCACCGCAGCAAT }\end{array}$ & 100 \\
\hline
\end{tabular}

${ }^{\mathrm{a}} \mathrm{F}_{\mathrm{c}}=$ forward primer designed to amplify $r p f F$ for cloning, $\mathrm{R}_{\mathrm{c}}=$ forward primer designed to amplify $r p f F$ for cloning, $\mathrm{F}_{\mathrm{qPCR}}=$ forward primer designed for $r p f F$ detection by quantitative polymerase chain reaction (qPCR), and $\mathrm{R}_{\mathrm{qPCR}}=$ reverse primer designed for $r p f F$ detection by $\mathrm{qPCR}$.

targeting genes that had previously been found to positively respond to DSF in $X$. citri (Guo et al. 2012) was designed using Primer Express 3.0 software (Applied Biosystems) (Table 2). Leaf disks taken from a given leaf were put in a mortar and macerated while frozen with liquid nitrogen, and RNA was extracted using the specifications for RNeasy mini kit (Qiagen). cDNA synthesis was then performed using a RevertAid First Strand cDNA Synthesis Kit (Thermo Scientific). The gene encoding $16 \mathrm{~S}$ ribosomal RNA was used as an internal control, and two qRT-PCRs were performed on each cDNA sample using the SYBR-green mix and the universal conditions of amplification provided by the 7500 System (Applied Biosystems). Dissociation curves were assessed in every amplification to verify the presence of a single amplicon. The results were analyzed by the 7500 System software (Applied Biosystems) using the relative quantification mode.

\section{XccDSF reporter assay.}

The methodology was done according to Beaulieu and associates (2013). Briefly, cells were recovered from colonies grown in solid medium with $2(\mathrm{Z})$-dodecenoic acid (XccDSF) or sap from WT and Carrizo citrange transgenic plants with or without the XccDSF. The negative control was biosensor cells grown without sap or DSF. The positive control was biosensor cells incubated with $3 \mu \mathrm{M} X c c$ DSF. The relative DSF abundance was estimated from the cells exhibiting GFP fluorescence from three replicate samples. GFP fluorescence was normalized as relative fluorescence units (RFU) per $\mathrm{OD}_{600}$. RFU was measured using a Synergy 2 Multi-Mode microplate reader (BioTek, Inc.).

\section{Xylella fastidiosa DSF reporter assay.}

Aiming to verify whether the sap collected from transgenic plants could trigger the expression of genes regulated by DSF, we used a Xylella fastidiosa bioreporter (Beaulieu et al. 2013) in which the $p h o A$ reporter gene is under control of the DSFresponsive $h x f A$ promoter, as described by Lindow and associates (2014). Inoculum of the $X$. fastidiosa bioreporter strain was grown for 5 to 6 days at $28^{\circ} \mathrm{C}$ on periwinkle gelrite me- dium (PWG) plates containing gentamicin at $10 \mu \mathrm{g} / \mathrm{ml}$. The cells were washed and resuspended in PBS buffer and $15 \mu \mathrm{l}$ of the cells was mixed with sap from $\mathrm{Ca} \_r p f F-1, \mathrm{Ca} \_r p f F-2$, and WT plants and incubated in PWG medium at $28^{\circ} \mathrm{C}$ for 4 days. The cells were collected with a swab and suspended in $400 \mu \mathrm{l}$ of water in wells of a Falcon 48-well tissue culture plate (Becton Dickenson, Franklin Lakes, NJ, U.S.A.) and centrifuged for 10 min at 2,254 $\times g$ in an Eppendorf model 5804 centrifuge (Eppendorf, Hamburg, Germany), and water was removed by aspiration. Alkaline phosphatase activity was accessed after $72 \mathrm{~h}$ of incubation, as described by Lindow and associates (2014). Enzyme activity was calculated as the rate of increase of fluorescence with time divided by the cell density.

\section{ACKNOWLEDGMENTS}

We thank F. de Assis A. Mourão-Filho and L. C. L. Stipp from Escola Superior de Agricultura "Luiz de Queiroz"/Universidade de São Paulo for assistance in citrus transformation; L. F. C. da Silva from Centro de Citricultura "Sylvio Moreira"-IAC for greenhouse plant propagation; P. H. Nunes from Universidade Estadual de São Paulo-UNESP/Rio Claro for assistance in microscopy analyses; and E. S. Antonova from University of California, Berkeley, for helping in the biosensor assays. This work was supported by research grants from Fundação de Amparo à Pesquisa do Estado de São Paulo (FAPESP 2010/50840-7 and 2013/17485-7) and Conselho Nacional de Desenvolvimento Científico e Tecnológico (CNPqINCT-Citros 08/57909-2, 573848/08-4). R. Caserta is a fellow Ph.D. from FAPESP (09/50253-7); and M. A. Takita, M. A. Machado, and A. A. De Souza are recipients of research fellowships from $\mathrm{CNPq}$.

\section{LITERATURE CITED}

An, G., Ebert, P. R., Miltra, A., and Ha, S. B. 1988. Binary vectors. Pages 1-19 in: Plant Molecular Biology Manual, A3. S. B. Gelvin, R. A. Schilperoort, and D. P. S. Verma, eds. Kluwer, Dordrecht, The Netherlands.

Beaulieu, E. D., Ionescu, M., Chatterjee, S., Yokota, K., Trauner, D., and Lindow, S. 2013. Characterization of a diffusible signaling factor (DSF) from Xylella fastidiosa. mBio 4:e00539-12.

Brunings, A. M., and Gabrieal, D. W. 2003. Xanthomonas citri: Breaking the surface, Mol. Plant Pathol. 4:141-157.

Chatterjee, S., Almeida, R. P. P., and Lindow, S. 2008a. Living in two 
Worlds: The Plant and Insect Lifestyles of Xylella fastidiosa Annu. Rev. Phytopathol. 46:243-271.

Chatterjee, S., Wistrom, C., and Lindow, S. E. 2008b. A cell-cell signaling sensor is required for virulence and insect transmission of Xylella fastidiosa. Proc. Natl. Acad. Sci. U.S.A. 105:2670-2675.

Denness, L., McKenna, J. F., Segonzac, C., Wormit, A., Madhou, P., Bennett, M., Mansfield, J., Zipfel, C., and Hamann, T. 2011. Cell wall damage-induced lignin biosynthesis is regulated by a reactive oxygen species- and jasmonic acid-dependent process in Arabidopsis. Plant Physiol. 156:1364-1374.

De Souza A. A., Ionescu M., Baccari C., da Silva A. M., and Lindow S. E. 2013. Phenotype overlap in Xylella fastidiosa is controlled by the cyclic Di-GMP phosphodiesterase Eal in response to antibiotic exposure and diffusible signal factor-mediated cell-cell signaling. Appl. Environ. Microbiol. 79:3444-3454.

Dong, Y. H., Wang, L. H., Xu, J. L., Zhang, H. B., Zhang, X. F., and Zhang, L. H. 2001. Quenching quorum-sensing-dependent bacterial infection by an $N$-acyl homoserine lactonase. Nature 411:813-817.

Dow, J. M., Crossman, L., Findlay, K., He, Y. Q., Feng, J. X., and Tang, J. L. 2003. Biofilm dispersal in Xanthomonas campestris is controlled by cell-cell signaling and is required for full virulence to plants. Proc. Natl. Acad. Sci. U.S.A. 100:10995-11000.

Facincani, A. P., Moreira, L. M., Soares, M. R., Ferreira, C. B., Ferreira R. M., Ferro, M. I. T., Ferro, J. A., Gozzo, F. C., and de Oliveira, J. C. F. 2013. Comparative proteomic analysis reveals that T3SS, Tfp, and xanthan gum are key factors in initial stages of Citrus sinensis infection by Xanthomonas citri subsp. citri. Funct. Integr. Genomics 14:205-217.

Gabriel, D. W. 1999. The Xanthomonas avr/pth gene family. Pages 39-55 in: Plant-Microbe Interactions, Vol. 4. G. Stacey and N. T. Keen, eds. American Phytopathological Society Press, St. Paul, MN, U.S.A.

González, J. E., and Keshavan, N. D. 2006. Messing with bacterial quorum sensing. Microbiol. Mol. Biol. Rev. 70:859-875.

Guo, Y., Zhang, Y., Li, J. L., and Wang, N. 2012. Diffusible signal factormediated quorum sensing plays a central role in coordinating gene expression of Xanthomonas citri subsp. citri. Mol. Plant-Microbe Interact. 25:165-179.

He, Y. W., Wu, J., Cha, J. S., and Zhang, L. H. 2010. Rice bacterial bligh pathogen Xanthomonas oryzae pv. oryzae produces multiple DSF-family signals in regulation of virulence factor production. BMC Microbiol. 10:187.

Ionescu, M., Baccari, C., Da Silva, A. M., Garcia, A., Yokota, K., and Lindow, S. E. 2013. Diffusible signal factor (DSF) synthase RpfF of Xylella fastidiosa is a multifunction protein also required for response to DSF. J. Bacteriol. 195:5273-5284.

Kaplan, H. B., and Greenberg, E. P. 1985. Diffusion of autoinducer is involved in regulation of the Vibrio fischeri luminescence system. J. Bacteriol. 163:1210-1214.

Lindow, S., Newman, K., Chatterjee, S., Baccari, C., Lavarone, A. T., and Ionescu, M. 2014. Production of Xylella fastidiosa diffusible signal factor in transgenic grape causes pathogen confusion and reduction in severity of Pierce's disease. Mol. Plant-Microbe Interact. 27:244-254.

Mäe, A., Montesano, M., Koiv, V., and Palva, E. T. 2001. Transgenic plants producing the bacterial pheromone $N$-Acyl homoserine lactone exhibit enhanced resistance to the bacterial phytopathogen Erwinia carotovora. Mol. Plant-Microbe Interact. 14:1035-1042.

Malamud, F., Torres, P. S., Roeschlin, R., Rigano, L. A., Enrique, R. Bonomi, H. R., Castagnaro, A. P., Marano, M. R., and Vojnov, A. A.
2011. The Xanthomonas axonopodis pv. citri flagellum is required for mature biofilm and canker development. Microbiology 157:819-829.

Malamud, F., Homem, R. A., Conforte, V. P., Yaryura, P. M., Castagnaro, A. P., Marano, M. R., Amaral, A. M., and Vojnov, A. A. 2013. Identification and characterization of biofilm formation-defective mutants of Xanthomonas citri subsp. citri. Microbiology 159:1911-1919.

Manefield, M., Rasmussen, T. B., Henzter, M., Andersen, J. B., Steinberg, P., Kjelleberg, S., and Givskov, M. 2002. Halogenated furanones inhibit quorum sensing through accelerated LuxR turnover. Microbiology 148:1119-1127.

Murashige, T., and Skoog, F. 1962. A revised medium for rapid growth and bioassays with tobacco tissue cultures. Physiol. Plant. 15:473-497.

Niki, T., Mitsuhara, I., Seo, S., Ohtsubo, N., and Ohashi, Y. 1998. Antagonistic effect of salicylic acid and jasmonic acid on the expression of pathogenesis-related (PR) protein genes in wounded mature tobacco leaves. Plant Cell Physiol. 39:500-507.

Novick, R. P., Projan, S. J., Kornblum, J., Ross, H. F., Ji, G., Kreiswirth, B., Vandenesch F., and Moghazeh S. 1995. The agr P2 operon: An autocatalytic sensory transduction system in Staphylococcus aureus. Mol. Gen. Genet. 248:446-458.

Panopoulos, N. J., and Schrost, M.N. 1974. Role of flagellar motility in the invasion of bean leaves by Pseudomonas phaseolicola. Phytopathology 64:1389-1397.

Popham, P. L., Pike, S. M., Novacky, A., and Pallardy, S. G. 1993. Water relation alterations observed during hypersensitive reaction lnduced by bacteria. Plant Physiol. 103: 1243-1247.

Ren, D., Sims, J. J., and Wood, T. K. 2001. Inhibition of biofilm formation and swarming of Escherichia coli by (5Z)-4-bromo-5-(bromomethylene)-3-butyl-2(5H)-furanone. Environ. Microbiol. 3:731-736.

Rigano, L. A., Siciliano, F., Enrique, R., Sendín, L., Filippone, P., Torres, P. S., Qüesta, J., Dow, J. M., Castagnaro, A. P., Vojnov, A. A., and Marano, M. R. 2007. Biofilm formation, epiphytic fitness, and canker development in Xanthomonas axonopodis pv. citri. Mol. Plant-Microbe Interact. 20:1222-1230.

Ryan, R. P., and Dow, J. M. 2011. Communication with a growing family: Diffusible signal factor (DSF) signaling in bacteria. Trends Microbiol. 19:145-152.

Seed, P. C., Passador, L., and Iglewski, B. H. 1995. Activation of the Pseudomonas aeruginosa las I gene by LasR and the Pseudomonas autoinducer PAI: An autoinduction regulatory hierarchy. J. Bacteriol. 177:654-659

Simionato, A. V. C., da Silva, D. S., Lambais, M. R., and Carrilho, E. 2007. Characterization of a putative Xylella fastidiosa diffusible signal factor by HRGC-EI-MS. J. Mass Spectrom. 42:1375-1381.

Swarup, S., Yang, Y., Kingsley, M. T., and Gabriel, D. W. 1992 A Xanthomonas citri pathogenicity gene, pthA, pleiotropically encodes gratuitous avirulence on nonhosts. Mol. Plant-Microbe Interact. 5:204-213.

Wang, L. H., He, Y., Gao, Y., Wu, J. E., Dong, Y. H., He, C., Wang, S. X. Weng, L. X., Xu, J. L., Tay, L., Fang, R. X., and Zhang, L. H. 2004. A bacterial cell-cell communication signal with cross-kingdom structural analogues. Mol. Microbiol. 51:903-912.

\section{AUTHOR-RECOMMENDED INTERNET RESOURCE}

National Center for Biotechnology Information BlastN and BlastX database: www.ncbi.nlm.nih.gov/sutils/genom_table.cgi 